\title{
Achieving the Triple Dividend in Portugal: A Dynamic General-Equilibrium Evaluation of a Carbon Tax Indexed to Emissions Trading (*)
}

\author{
Alfredo Marvão Pereira** \\ The College of William and Mary \\ Rui M. Pereira \\ The College of William and Mary
}

College of William and Mary

Department of Economics

Working Paper Number 155

First Version: December 2014

This Version: May 2015 


\title{
Achieving the Triple Dividend in Portugal: A Dynamic General-Equilibrium Evaluation of a Carbon Tax Indexed to Emissions Trading (*)
}

\begin{abstract}
Using an applied dynamic general-equilibrium model, we simulate the environmental, economic, and budgetary effects in Portugal of a new carbon tax indexed to the carbon price in the EU-ETS market. Through careful recycling of the carbon-tax revenues to finance lower personal income taxes, lower Social Security contributions, and higher investment tax credits - in particular when these changes are directed at promoting energy efficiency - we show that a carbon tax reform can yield three dividends of a long-lasting nature: a reduction in emissions, better economic performance, and a stronger budgetary position. Thus, we show that it is possible to design a politically-feasible carbon tax reform that not only boosts economic growth and strengthens fiscal consolidation, but also accommodates the legitimate needs of different stakeholders: interest groups that target environmental goals, households focused distributional issues, and businesses concerned with international competitiveness. These views were fully incorporated in a draft bill presented to the Portuguese Government in September 2014 by the Commission for Environmental Tax Reform [CRFV (2014)]. Based on these recommendations, a new indexed carbon tax was then approved by Parliament, and enacted on January $1^{\text {st }}, 2015$.
\end{abstract}

Keywords: Carbon Taxation; Economic Effects; Budgetary Effects; Three Dividends; Dynamic General- Equilibrium; Endogenous Growth; Portugal.

JEL Classification: D58, H63, O44.

\author{
Alfredo Marvão Pereira \\ Department of Economics, \\ The College of William and Mary, Williamsburg, USA \\ PO Box 8795, Williamsburg, VA 23187 \\ ampere@wm.edu \\ Rui M. Pereira \\ Department of Economics, \\ The College of William and Mary, Williamsburg, USA \\ PO Box 8795, Williamsburg, VA 23187 \\ rmpereira@wm.edu
}




\section{Introduction}

In Portugal, the last two decades have been marked by substantial developments in the energy sector and in carbon dioxide emissions from fossil fuel combustion activities. These activities account for the bulk of greenhouse gas (GHG) emissions from energy activities, and about $70 \%$ of total greenhouse gas emissions in the country. These GHG emissions grew 57\% between 1990 and 2005, reaching 64.1 $\mathrm{Mt} \mathrm{CO}_{2}$, their highest level in twenty years. Together, the introduction of natural gas in the late 1990s, the effective promotion of renewable energies, as well as the European Union's Emissions Trading System (EU-ETS) have allowed for a 25\% reduction in emissions between 2005 and 2012 - in part, driven by the economic downturn and the global financial crisis. Following these positive outcomes, together with other Member States of the European Union, Portugal has set forth an ambitious program to reduce emissions by 40\% in 2030, relative to 1990 levels [see, for example, European Union (2013)].

One of the cornerstones of the current efforts is the introduction of a new carbon tax. Indeed, in early 2014 the Government appointed a Commission to study and make specific proposals in terms of environmental tax reform in Portugal, and one of the most emblematic ideas proposed was the introduction of a carbon tax. The purpose of this article is to present and discuss the environmental, economic and budgetary effects of such a new carbon tax in Portugal. Our results were fully integrated in the final proposal that this environmental tax reform commission submitted to the Portuguese Government in September 2014 [see, Comissão para a Reforma Fiscal Ambiental - CRFV (2014)].

We focus on the issue of the multiple dividends of a carbon tax and the role of recycling the revenues of this tax to generate such dividends [see, for example, Pereira and Pereira (2014b)]. Clearly a carbon tax would reduce emissions, and thereby generate a first dividend, an environmental dividend. It would, however, negatively affect economic performance and possibly worsen the 
budgetary position. These negative side-effects of the carbon tax can, however, be mitigated - or even reversed - in the context of revenue-neutral tax reform where the carbon tax revenues are recycled in a way that alleviates distortions at other tax margins. In terms of the second dividend, the economic dividend, a strong realization refers to the possibility of achieving an actual improvement in economic performance compared to the pre-carbon tax situation. In terms of the third dividend, a budgetary dividend, a strong realization refers to an overall reduction in the public-debt-to-GDP position, compared to the pre-tax situation. In both cases a weak realization of the dividend refers to situations in which the losses induced by the introduction of the carbon tax are merely mitigated but not reversed through recycling. In light of the terms of the policy debate in Portugal - the quest for economic growth and the ongoing need for fiscal consolidation - in this article we focus on identifying those cases where the strong realizations of the second and third dividends occur.

The environmental, economic, and budgetary effects of a new carbon tax are analyzed in the context of a dynamic general-equilibrium model of the Portuguese economy which features endogenous growth and a detailed modeling of all major public-sector activities. Specifically, the model incorporates fully-dynamic optimization behavior, endogenous growth mechanisms, and a detailed modeling of public spending, as well as Social Security contributions and tax revenues.. Previous versions of this model have been used to evaluate the impact of tax policy [see Pereira and Rodrigues (2002, 2004)], public pension reform [see Pereira and Rodrigues (2007)], as well as energy and climate policy [see Pereira and Pereira (2013, 2014a, 2014b, 2014c)].

This model brings together two important strands of the taxation literature [see the above applications of this model for a detailed list of the references]. On one hand, it follows in the footsteps of computable general-equilibrium modeling. It shares with this literature the ability to consider the tax system in great detail. This is important, given the evidence that both the costs and the effectiveness of climate policies are influenced by existing tax distortions [see, for example, 
Goulder (1995), Goulder et al (1999), Goulder et al (2008), Marron and Toder (2014), and Parry (2014)]. On the other hand, it incorporates many of the insights of the endogenous growth literature. In particular, it recognizes that public policies have the potential to affect the fundamentals of long-term growth, and not just for generating temporary level effects [see, for instance, Xepapadeas (2005), Fullerton and Kim (2008)], and Oueslati (2014, 2015)].

The impact of climate policy on economic performance has been a central part of the policy debate [see, amongst others, Nordhaus (1993a, 1993b), Babiker et al. (2003), Dissou (2005), Stern (2007), Rivers, (2010), and Morris et al. (2012)]. In addition, in recent years, we have witnessed a growing concern over mounting public indebtedness, and the need to achieve long-term fiscal sustainability. In this context, $\mathrm{CO}_{2}$ taxes and auctioned emissions permits have emerged as potentially important policy instruments for increasing public revenues [see, for example, Metcalf and Weisbach (2008), Galston and MacGuineas (2010), Metcalf (2010), and Nordhaus (2010)].

The interactions between climate policy, economic growth and the public-sector account are fundamental, since they correlate to some of the most important policy constraints faced by energyimporting economies in their pursuit of sound climate policies: i.e., the need to enact policies that not only promote long-term growth, but also improve budgetary positions. As European Union (EU) structural transfers have shifted towards new members, countries such as Ireland, Greece, and Portugal have been forced to rely more and more on domestic public policies to promote real convergence. This fact poses quite a challenge, since growing public spending, counter-cyclical policies, and more recently, falling tax revenues have all contributed to rapidly-increasing levels of public debt and a sharp need for budgetary consolidation.

The remainder of this article proceeds as follows. In Section 2 we present the dynamic general-equilibrium model. In Section 3, we discuss the environmental, economic, and budgetary effects of a carbon tax, under the assumption that the tax revenues it generates are recycled back 
into the economy in a lump-sum manner. In Section 4, we consider the carbon tax under a variety of alternative revenue-recycling mechanisms to identify key strategies that mitigate or reverse any potential negative economic and budgetary effects of this tax. In Section 5, we present sensitivity analysis with respect to the assumed level of carbon taxation. Finally, in Section 6, we provide a summary of our simulation results, and wrap up with a few detailed policy recommendations.

\section{The Dynamic General-Equilibrium Model of the Portuguese Economy}

In this section we present the model in very general terms. Complete model documentation with detailed descriptions of the model equations, parameters, data, calibration, and numerical implementation, can be found in Pereira and Pereira (2012).

We consider a decentralized economy in a dynamic general-equilibrium framework. All agents are price-takers and have perfect foresight. With money absent, the model is framed in real terms. There are four sectors in the economy - the production sector, the household sector, the public sector and the foreign sector. The first three have endogenous behavior, but all four sectors are interconnected through competitive market equilibrium conditions, as well as the evolution of the stock variables and the relevant shadow prices. All markets are assumed to clear.

The trajectory for the economy is described by the optimal evolution of eight stock and five shadow price variables - private capital, wind energy capital, public capital, human capital, and public debt, together with their shadow prices, and foreign debt, private financial wealth, and human wealth. In the long term, endogenous growth is determined by the optimal accumulation of private capital, public capital and human capital. The last two are publicly provided.

\subsection{The Production Sector}

Aggregate output is produced with a Constant Elasticity of Substitution (CES) technology, linking value added and primary energy demand. Value added is produced according to a Cobb- 
Douglas technology exhibiting constant returns to scale in the reproducible inputs - effective labor inputs, private capital, and public capital. Only the demand for labor and the private capital stock are directly controlled by the firm, meaning that, if public investment is absent, then decreasing returns set in. Public infrastructure and the economy-wide stock of knowledge are publicly financed and are positive externalities. Primary energy demand is produced according to a CES technology using crude oil inputs and non-transportation energy sources. The production of non-transportation energy follows a Cobb-Douglas technology using coal, natural gas and wind energy inputs.

Private capital accumulation is characterized by a dynamic equation of motion where physical capital depreciates. Gross investment is dynamic in nature with its optimal trajectory induced by the presence of adjustment costs. These costs are modeled as internal to the firm - a loss in capital accumulation due to learning and installation costs - and are meant to reflect rigidities in the accumulation of capital towards its optimal level. Adjustment costs are assumed to be nonnegative, monotonically increasing, and strictly convex. In particular, we assume adjustment costs to be quadratic in investment per unit of installed capital.

The firms' net cash flow represents their after-tax position when revenues from sales are netted of wage payments and investment spending. After-tax net revenues reflect the presence of a private investment and wind energy investment tax credits, as well as taxes on corporate profits and Social Security contributions paid by the firms on gross salaries.

Buildings make up a fraction of total private investment expenditure. Only this fraction is subject to value-added and other excise taxes, the remainder is exempt. The corporate income tax base is calculated as revenues from the sale of output, net of total labor costs, and net of fiscal depreciation allowances over past and present capital investments. A straight-line fiscal depreciation method is used, and investment is assumed to grow with output. Under these assumptions, depreciation allowances are simply proportional to the difference of two infinite geometric sums. 
Optimal production behavior consists in choosing the levels of investment and labor that maximize the present value of the firms' net cash flows, subject to the equation of motion for private capital accumulation. The demands for labor and investment are obtained from the currentvalue Hamiltonian function, where the shadow price of private capital evolves according to the respective co-state equation. Finally, with regard to the firm's financial link with the rest of the economy, we assume that at the end of each operating period the net cash flow is transferred back to the households.

\subsection{The Energy Sector}

We consider the introduction of $\mathrm{CO}_{2}$ taxes levied on primary energy purchased by firms. This is consistent with the nature of the existing policy environment in Portugal in which $\mathrm{CO}_{2}$ permits may now be auctioned off to firms. Furthermore, evidence suggests that administrative costs are substantially lower the further upstream the tax is administered. By considering taxation at the firm level, the additional costs induced by $\mathrm{CO}_{2}$ taxes are transmitted through the economy in a fashion consistent with the energy content of the different goods. Not levying the $\mathrm{CO}_{2} \operatorname{tax}$ on consumers therefore avoids a double taxation of the carbon content of a good.

The energy sector is an integral component of the firms' optimization decisions. We consider primary energy consumption by firms for crude oil, coal, natural gas and wind energy. Primary energy demand refers to the direct use of an energy vector at the source, in contrast to energy resources that undergo a conversion or transformation process.

Primary energy consumption provides the most direct approach for accounting for $\mathrm{CO}_{2}$ emissions from fossil fuel combustion activities. Carbon is released from fossil fuel upon combustion. Together, the quantity of fuel consumed, its carbon factor, oxidation rate, and the ratio of the molecular weight of $\mathrm{CO}_{2}$ to carbon are used to compute the amount of $\mathrm{CO}_{2}$ emitted from fossil fuel combustion activities in a manner consistent with a reference approach suggested by the 
Table 1

Carbon Dioxide Emission Factor by Fuel

\begin{tabular}{|c|c|c|c|c|c|c|}
\hline Fuel types & Unit & $\begin{array}{c}\text { Conversion } \\
\text { factor } \\
\text { (TJ/Unit) }\end{array}$ & $\begin{array}{l}\text { Carbon } \\
\text { emission } \\
\text { factor } \\
\text { (tC/TJ) }\end{array}$ & $\begin{array}{c}\text { Carbon } \\
\text { content } \\
(\mathrm{Gg} \mathrm{C})\end{array}$ & $\begin{array}{c}\text { Fraction of } \\
\text { carbon } \\
\text { oxidized }\end{array}$ & $\begin{array}{c}\text { Actual } \mathrm{CO}_{2} \\
\text { emissions } \\
(\mathrm{Gg} \mathrm{CO})_{2}\end{array}$ \\
\hline Crude Oil & toe & 0.041868 & 20.00 & 0.84 & 0.99 & 3.04 \\
\hline Bituminous Coal & toe & 0.041868 & 25.10 & 1.05 & 0.98 & 3.78 \\
\hline Natural Gas (Dry) & toe & 0.041868 & 15.30 & 0.64 & 1.00 & 2.34 \\
\hline
\end{tabular}

Sources: Intergovernmental Panel for Climate Change (2006) and authors' calculations

Intergovernmental Panel for Climate Change (2006). These considerations suggest a linear relationship between $\mathrm{CO}_{2}$ emissions and fossil fuel combustion activities.

Fossil fuels are hydrocarbons defined by the relative amounts of carbon and hydrogen in each molecule. In the combustion reaction, the compound reacts with an oxidizing element, such as oxygen. Thus, the amount of carbon relative to hydrogen in the fuel determines the fuel's carbon emissions factor, i.e., the amount of carbon emitted per unit of energy. The molecular weight of carbon dioxide $\mathrm{CO}_{2}$ is 44/12 times greater than the weight of carbon alone (the molecular weight of carbon is 12 and that of oxygen is 16 which give $\mathrm{CO}_{2}$ a weight of 44 moles and carbon of 12 moles). The fuel's $\mathrm{CO}_{2}$ emission factor can be computed from the product of its carbon-emission factor, in tons of oil equivalent, the fraction of carbon oxidized and the ratio of the molecular weight of carbon dioxide to carbon. These computations are given in Table 1. For each ton of oil equivalent consumed, crude oil yields $3.04 \mathrm{tCO}_{2}$, coal yields $3.78 \mathrm{tCO}_{2}$, and natural gas yields $2.34 \mathrm{tCO}_{2}$.

Aggregate primary-energy demand is produced with a CES technology, in which crude oil, and non-transportation fuels are substitutable at a rate of less than unity, which reflects the dominance of petroleum products in transportation energy demand, and the ubiquity of coal, natural gas and - to a lesser extent - wind energy, in electric power and industry. Non-transportation fuels are produced with a Cobb-Douglas technology that takes into account the relatively greater potential 
for substitution in electric power and industry. The accumulation of wind energy infrastructure is governed by a dynamic equation of motion where physical capital - wind turbines - depreciates, and investment is subject to adjustment costs, just as in the case of private capital. Wind energy investment decisions are internal to the firm, while coal, natural gas and oil are imported.

Optimal primary energy demand is derived by maximizing the present value of the firms' net cash flows, as discussed above. In turn, the demand for coal and natural gas are defined through the nested dual problem of minimizing energy costs, given the production function and optimal demand for these energy vectors in electric power and industry. Finally, the variational condition for optimal wind energy investment and the equation of motion for the shadow price of wind energy are defined by differentiating the Hamiltonian with respect to wind energy investment and its stock.

\subsection{The Households}

An overlapping-generations specification was adopted in which the planning horizon is finite but in a non-deterministic fashion. A large number of identical agents are faced each period with a probability of survival. The assumption that the probability of survival is constant over time and across age cohorts yields a perpetual youth specification. Without loss of generality, the population, which is assumed to be constant, is normalized to one. Therefore, per capita and aggregate values are equal.

The household chooses consumption and leisure streams that maximize intertemporal utility, subject to a consolidated budget constraint. The objective function is subjectively discounted lifetime-expected utility. Preferences are additively separable in consumption and leisure, and take on the CES form. A lower probability of survival reduces the effective discount factor, thus making the household relatively more impatient.

The budget constraint reflects a value-added tax on consumption, and states that the households' expenditure stream, discounted at the after-tax market real interest rate, cannot exceed 
total wealth. The loan rate at which households borrow and lend among themselves is greater than the after-tax interest rate, thus reflecting the probability of survival.

Total wealth is age-specific and is composed of human wealth, net financial worth, and the present value of the firm. Human wealth represents the present discounted value of the household's future labor income stream, net of personal income taxes and workers' social security contributions. The household's wage income is determined by its endogenous decision of how much labor to supply out of a total time endowment, and by the stock of knowledge or human capital that is augmented by public investment in education. Labor earnings are discounted at a higher rate, reflecting the probability of survival.

A household's income increases with net interest payments received on public debt, profits distributed by corporations, international transfers, and also with public transfers. On the spending side, debts to foreigners are serviced, taxes are paid and consumption expenditures are made. Income, net of spending, adds to net financial wealth. Under the assumption of no bequests, households are born without any financial wealth. In general, total wealth is age-specific due to agespecific labor supplies and consumption streams.

Assuming a constant real interest rate, the marginal propensity to consume out of total wealth is age-independent and aggregation over age cohorts is greatly simplified. This allows us to write the aggregate demand for leisure as a function of aggregate consumption.

\subsection{The Public Sector}

The equation of motion for public debt reflects the fact that the excess of government expenditures over tax revenues has to be financed with further public debt. Total tax revenues include personal income taxes, corporate income taxes, value-added taxes, and social security taxes levied on firms as well as on workers. All of these taxes are levied on endogenously-determined tax bases. Residual taxes are modeled as lump sum, and are assumed to grow at an exogenous rate. 
The public sector pays interest to service its public debt, and transfers funds to households in the form of pensions, unemployment subsidies, and social transfers, which grow at an exogenous rate. In addition, it engages in public consumption activities and public investment in both public capital and human capital.

Public investments are determined optimally, respond to economic incentives, and constitute an engine of endogenous growth. The accumulations of human capital and public capital are subject to depreciation and adjustment costs, which are a fraction of the respective investment levels. The adjustment cost functions are strictly convex and quadratic.

Public-sector decisions consist of choosing the trajectories for public consumption, public investment in human capital and public investment in public capital that maximize social welfare, defined as the net present value of the future stream of utility derived from public consumption, parametric on household private consumption-leisure decisions. The optimal choice is subject to three constraints, the equations of motion of the stock of public debt, the stock of public capital, and the stock of human capital. The optimal trajectories depend on the shadow prices of public debt, public capital, and human capital stocks, respectively. Optimal conditions are defined for public debt, for public consumption, for public investment, and for investment in human capital.

\subsection{The Foreign Sector}

The equation of motion for foreign financing provides a stylized description of the balance of payments. Domestic production and imports are absorbed by domestic expenditure and exports. Net imports incorporate payments by firms for fossil fuels, and are financed through foreign transfers and foreign borrowing. Foreign transfers are assumed to grow at an exogenous rate. Portugal is modeled as a small, open economy. This means that it can obtain the desired level of foreign financing at a rate which is determined in international financial markets. This is the prevailing rate for all domestic agents. 


\subsection{The Intertemporal Market Equilibrium}

The intertemporal path for the economy is described by the behavioral equations, by the equations of motion of the stock and shadow price variables, and by the market equilibrium conditions. The labor-market clearing condition incorporates an exogenous structural unemployment rate. The product market equalizes demand and supply for output. Given the open nature of the economy, part of domestic demand is satisfied through the recourse to foreign production. Finally, equilibrium in the financial market reflects the fact that private capital formation and public indebtedness are financed by household savings and foreign financing.

We define the steady-state growth path as an intertemporal equilibrium trajectory in which all the flow and stock variables grow at the same rate, $g$, while market prices and shadow prices are constant. There are three types of restrictions imposed by the existence of a steady state. First, it determines the value of critical production parameters, like adjustment costs and depreciation rates, given the initial capital stocks. These stocks, in turn, are determined by assuming that the observed levels of investment of the respective type are such that the ratios of capital to GDP do not change in the steady state. Second, the need for constant public-debt and foreign debt-to-GDP ratios implies that the steady-state public-account deficit and the current -account deficit are a fraction, $g$, of the respective stocks of debt. Finally, the exogenous variables, such as public transfers or international transfers, have to grow at the steady-state growth rate.

\subsection{Dataset, Parameter Specification, and Calibration}

The model is implemented numerically using detailed data and parameters sets. Economic data are from the Statistical Annex of the European Community [European Commission (2014d)], budgetary data are from the Portuguese Ministry of Finance [GPEARI (2014)], and energy and environmental data are from the Portuguese Ministry of Economy [DGEG (2014)]. The 
decomposition of the aggregate variables follows the average for the period 2000-2013 for macroeconomic data, as well as for the energy variables. This period was chosen to reflect the most recent available information and to cover several business cycles, thereby reflecting the long-term nature of the model. Public debt and foreign debt, as well as the stocks of capital, reflect the most recent available data, i.e., the end of 2013.

Parameter values are specified in different ways. Whenever possible, parameter values are taken from the available data sources or the literature. This is the case, for example, of the population growth rate, the probability of survival, the share of private consumption in private spending, and the different effective tax rates.

All the other parameters are obtained by calibration; i.e., in a way that the trends of the economy for the period 2000-2013 are extrapolated as the steady-state trajectory. In some cases, the calibration parameters are chosen freely, in that they are not implied by the state-state restrictions. Although free, these parameters have to be carefully chosen since their values affect the value of the remaining calibration parameters. Accordingly, they were chosen either using central values or using available data as guidance. For instance, the elasticity of substitution parameters are consistent with those values often applied in climate policy analysis [see, for example, Manne and Richels (1992), Paltsev et al. (2005) and Koetse et al. (2008)]. The remaining calibration parameters are implied by the steady-state restrictions.

\subsection{Establishing the Reference Case}

The reference case is based on the calibrated steady-state version of the model and considers the evolution of the international fossil fuel prices and the trends in domestic energy efficiency gains. Both are important drivers of emissions reductions, and both can have significant impacts in the economic and budgetary performance of the economy. More importantly, they frame the effort, in terms of the level of the carbon tax needed to reach the emissions targets. [For a comprehensive 
discussion on the relative role of international fossil fuel prices, energy efficiency, and carbon taxation in achieving future environmental targets in Portugal, see Pereira and Pereira (2014d)].

We begin by recognizing that Portugal is a small, open energy-importing economy, and therefore we consider the projected evolution of the fossil fuel prices - oil, coal, and natural gas - in international markets. We follow the central fossil-fuel price scenario forecasts used by the Portuguese Commission for Environmental Tax Reform [see Comissão para a Reforma da Fiscalidade Verde (2014)] and presented in great detail in Sena (2014).

The fossil-fuel price scenario is based primarily on two sources: The European Commission (EC) and futures markets - namely the Intercontinental Exchange. These two sources differ both in their temporal scope, as well as in the magnitude of the price changes expected for the future. In general, the EC forecasts suggest higher prices than the futures markets. The central fuel-price assumptions (reference scenario) are based on an average of the EC forecast and the futures-market data, extended with growth in prices derived from the EC forecast.

All fossil-fuel prices show an upward trend, with prices of coal and natural gas increasing by $20 \%$ and $26 \%$ in 2030, respectively, relative to their 2013 levels. The increase in the price of crude oil is less pronounced, with an increase of just $11 \%$. Accordingly, the price of coal increases, relative to natural gas, and both the prices of coal and natural gas increase substantially relative to crude oil.

We also consider the fact that improving energy efficiency is widely regarded as a key mechanism for lowering the energy intensity and the carbon intensity of the economy. Energy efficiency goals have been formalized in a number of EU directives. Most notable is EC Directive $2009 / 28 / E C$, which sets a legally binding target of increasing energy efficiency by $20 \%$ by 2020 , relative to 1990 levels, and the current working targets of energy efficiency gains in primary energy consumption of $21 \%$ by 2030 compared to 2007 levels [see, for example, European Commission (2013), (2014b)]. These targets imply an annual increase in energy efficiency of nearly $1 \%$. 
The energy intensity of the Portuguese economy, defined as the use of energy per Euro of GDP, is arguably a good measure of the overall productivity of energy resources in the economy. It grew through the $1980 \mathrm{~s}$ and $1990 \mathrm{~s}$ at an average annual rate of $1.6 \%$. In fact, the energy intensity of the economy reached its maximum value in 1999, reaching again similar values in 2005, despite a modest annual decline of $0.4 \%$ per year between 2000 and 2004. Since 2005, the energy intensity of the Portuguese economy has been on a downward trend, suggesting a greater productivity of energy resources, in general, and an improvement in efficiency, in particular. Between 2005 and 2009, the energy intensity of the Portuguese economy fell by an average of 1.6 percent per year. More recently, in 2011 and 2012, the energy intensity of the Portuguese fell by $0.7 \%$ and $1.7 \%$, respectively. For the decade, the energy intensity of the economy fell at an average annual rate of $1 \%$, a figure that is consistent with the targets set by the European Commission.

\section{The Effects of a Carbon Tax: Preliminary Discussion and Results}

In this section we discuss the choice of how high the carbon tax ought to be, and then identify the environmental, economic, and budgetary effects of this carbon tax in its simplest form i.e., when its revenues are returned to households as a lump sum.

\subsection{On the Choice of a Carbon Tax Indexed to the EU-ETS Carbon Price}

The choice of the carbon tax level is a delicate matter. There are fifteen countries which have introduced, or are about to introduce, carbon taxes. The levels and scope of taxation vary widely from a low of about 1.5 Euros per ton of $\mathrm{CO}_{2}$ in Japan and about 7 Euros per ton in Iceland covering $50 \%$ and $70 \%$ of domestic emissions respectively, to almost 115 Euros in the United Kingdom and 125 Euros in Sweden, although these cover only about 25\% of emissions in those countries. In about two-thirds of the countries, taxes range between 10 and 35 euros per ton and cover between 35\% and 70\% of emissions, [for more details, see, for example, World Bank (2014)]. 
Another reference point for the price of carbon is the market price for carbon in the European Union Emissions Trading System (EU-ETS). The average price for $\mathrm{CO}_{2}$ emissions allowances observed in the EU-ETS between 2006 and 2011 was 15 euros per ton. During this period, the price of carbon reached a maximum of 34 Euros per ton. Prices, however, have shown a great degree of volatility, having in recent years reached rather low levels over weak aggregate demand - 8 Euros per $\mathrm{tCO}_{2}$ in 2012, 4.7 Euros in 2013, and about 6 Euros in 2014.

Given this evidence, a reasonable reference point would be a carbon tax of 15-17 Euros per $\mathrm{tCO}_{2}$. This tax level is consistent with the recommendation in a recent report by the European Environmental Agency [see Anderson et al. (2013)] and is also indicative of the efforts required to meet domestic targets [see Pereira and Pereira (2013)]. This is also the average reference price for the sectors covered by the EU-ETS for the period from 2015 to 2030 [see, for example, European Commission (2014d)].

The choice of the level of carbon taxation in Portugal is further complicated by the fact that a significant part of the economy - corresponding to about $37 \%$ of the $\mathrm{CO}_{2}$ emissions - is currently already covered by the EU-ETS, and therefore already faces a price signal for carbon emissions. Accordingly, a new carbon tax would only apply to the sectors not already participating in this market - i.e., firms and sectors not covered by the EU-ETS would then face a price signal through the carbon tax, while those firms and sectors participating in the EU-ETS would face a price signal through the carbon market.

The remaining problem is that the two carbon price signals - the carbon tax and the carbon price in the EU-ETS - would, in general, be quite different, which is not altogether an efficient way of dealing with the issue. Furthermore, with the current low EU-ETS market price, a meaningful carbon tax would likely be higher than the carbon market price at present. In this case, the participating sectors, which are typically the most polluting ones, would face a lower carbon price. 
Again, this would be an undesirable outcome from an efficiency viewpoint. The option of leveling the two signals by imposing a high carbon tax level on non EU-ETS sectors, and simultaneously introducing a matching tax surcharge on the EU-ETS sectors, was not deemed to be politically feasible domestically, or legally unquestionable at the EU level.

The remaining option was to index the carbon tax to the carbon price in the EU-ETS market, although this means starting with a very low carbon tax of around 6 Euros per $\mathrm{tCO}_{2}$. This was the option adopted by the Environmental Tax Reform Commission [see CRFV (2014b)]. This option has two advantages. First, given the projected evolution of the carbon prices in the EU-ETS, this value is expected to increase rather significantly over time [again, see European Commission (2014d)]. This expected evolution would allow for a smooth transition into a significantly higher carbon price in the economy. Second, for the period until 2030, the expected evolution of the carbon price in the EU-ETS would be roughly equivalent to a flat annual tax of 17 euros per $\mathrm{tCO}_{2}$, a level of taxation that is well within the scope of what would be desirable for Portugal.

In this article, and unless otherwise indicated, the carbon tax level is indexed to the EU-ETS price, and therefore follows the path for the forecasts for the EU-ETS carbon price presented in European Commission (2014d). Specifically, carbon prices are projected to reach 10 euros per $\mathrm{tCO}_{2}$ by 2020 , and 35 euros by 2030. We assume they remain at this level thereafter. Furthermore, and without exceptions, only the sectors not participating in the EU-ETS are subject to this carbon tax. This means that only the revenues from this carbon tax with general, but not universal, applicability are considered, and in no case, for example, do we consider the revenues from permit auctions for the EU-ETS participants.

\subsection{The Effects of an Indexed Carbon Tax without Revenue Recycling}

We now examine the environmental, economic, and budgetary effects of the indexed carbon tax, as described above. We consider the carbon tax in its simplest form, i.e., where tax revenues are 
distributed through lump-sum transfers to households. Such a tax generally leads to favorable results in terms of emissions, a first dividend. It also leads to unfavorable outcomes in terms of its economic impacts, and sometimes even in terms of the budgetary impacts, that is, no second or third dividend. Results are presented in Table 2.

A $\mathrm{CO}_{2}$ tax works primarily through two mechanisms. First, by affecting relative prices, the $\mathrm{CO}_{2}$ tax induces firms to adjust their input structure, which in turn affects the marginal productivity of factor inputs. Second, the $\mathrm{CO}_{2}$ tax increases energy expenditure, and reduces the firms' net cash flow, household income, and domestic demand. These substitution and scale effects are central in understanding how carbon taxation affects energy consumption, emissions, economic performance and the public-sector account.

The $\mathrm{CO}_{2}$ tax increases the price of fossil fuels relative to renewable energy resources, and changes the relative price of the different fossil fuels to reflect their carbon content. This has a profound impact on the energy sector, driving a reduction in fossil-fuel consumption of $11.92 \%$ and an increase in the stock of wind energy infrastructure of $15.56 \%$ by 2030 . The impact of $\mathrm{CO}_{2}$ taxation on aggregate fossil-fuel demand, however, masks important changes in the fuel mix. In particular, we observe a $33.21 \%$ reduction in coal consumption, while crude oil falls by $8.55 \%$ and natural gas by $3.20 \%$. As such, the $\mathrm{CO}_{2}$ tax induces a shift in the energy mix, which favors wind energy, at the expense of coal. Ultimately, $\mathrm{CO}_{2}$ emissions are $13.13 \%$ lower in 2030 than in the reference scenario, which corresponds to about $18.3 \%$ of the emissions observed in 1990 .

$\mathrm{CO}_{2}$ taxation, by increasing energy-system costs, has a negative impact on the firms' net cash flow which limits the firms' demand for inputs. Employment falls by $0.31 \%$ in 2030 , less than the reduction in private investment of $2.15 \%$ and the associated drop in private capital of $1.16 \%$, and certainly substantially less than the drop in fossil-fuel demand. This is consistent with an overall 
reduction in input levels, coupled with a shift in the firms' input structure away from energy inputs, and an increasing role for capital and, especially, labor.

Given the reductions in factor demand, it is of no surprise that $\mathrm{CO}_{2}$ taxation has a negative impact on economic growth and activity levels. The reduction in the firms' net cash flow has a direct impact on household income, since it is an integral part of total wealth. This drives down private consumption, and initiates an important dynamic feedback between income, consumption and production. As a result, private consumption falls by $0.68 \%$. The net effect of this interaction is a reduction in GDP levels of $0.92 \%$ by 2030 .

We observe a reduction in exports and imports, in particular of fossil fuels. By 2030, fossilfuel imports are $10.66 \%$ lower than the reference levels. The reduction in domestic demand, coupled with lower expenditure on imported energy resources stemming from demand adjustments, suggests that foreign-debt-to-GDP levels fall by $3.67 \%$ in 2030 , relative to reference levels.

The indexed carbon tax in this simple implementation affects fiscal consolidation negatively. Simulation results suggest that the tax leads to a $1.74 \%$ increase in the public-debt to-GDP ratio by 2030 - which, using 2014 values as a reference point, is equivalent to a 2.2 p.p. increase in the publicdebt-to-GDP ratio. This effect is fundamentally due to a moderate reduction in public outlays, coupled with a small increase in overall tax revenues.

On the expenditure side, and given that all forms of public spending are modeled as exogenous and growing at the ongoing GDP growth rate, we observe a reduction in overall spending of $0.91 \%$ in 2030 . This closely follows the evolution of GDP itself, with the small differences induced by the evolution of interest payments on outstanding public debt. On the revenue side, a reduction in income, consumption and private inputs results in contracting tax bases. Accordingly, personal income tax revenues are $0.82 \%$ lower, corporate income tax revenue falls by $1.01 \%$, value-added tax receipts by $0.88 \%$, and Social Security contributions are $1.39 \%$ lower as well. 
Table 2

Effects of an Indexed Carbon Tax

With Lump-Sum Recycling

(Percent change with respect to reference scenario)

\begin{tabular}{|c|c|c|c|c|}
\hline & 2020 & 2025 & 2030 & 2050 \\
\hline \multicolumn{5}{|l|}{ Energy } \\
\hline Total Energy Demand & -3.26 & -5.72 & -7.80 & -6.86 \\
\hline Demand for Fossil Fuels & -5.04 & -8.78 & -11.92 & -11.32 \\
\hline Crude Oil & -3.10 & -6.04 & -8.55 & -8.44 \\
\hline Coal & -16.67 & -25.36 & -33.21 & -29.84 \\
\hline Natural Gas & -0.67 & -2.47 & -3.20 & -3.52 \\
\hline Investment in Wind Energy & 21.18 & 25.15 & 24.03 & 17.50 \\
\hline Wind Energy Infrastructures & 6.80 & 11.61 & 15.56 & 18.35 \\
\hline Carbon Dioxide Emissions from Fossil-Fuel Combustion & -5.68 & -9.70 & -13.13 & -12.37 \\
\hline \multicolumn{5}{|l|}{ Economy } \\
\hline Growth Rate of GDP (Percent Change over Previous Period) & 0.94 & 0.91 & 0.92 & 0.94 \\
\hline GDP & -0.17 & -0.54 & -0.92 & -1.55 \\
\hline Private Consumption & -0.67 & -0.67 & -0.68 & -0.71 \\
\hline Private Investment & -1.49 & -1.97 & -2.14 & -2.35 \\
\hline Private Capital & -0.42 & -0.79 & -1.16 & -1.96 \\
\hline Imported Energy & -3.92 & -7.55 & -10.66 & -11.46 \\
\hline Foreign Debt/GDP & -1.70 & -2.78 & -3.67 & -5.90 \\
\hline \multicolumn{5}{|l|}{ Labor Markets } \\
\hline Employment & 0.15 & -0.08 & -0.31 & -0.57 \\
\hline Wages & -0.47 & -0.76 & -1.03 & -1.17 \\
\hline \multicolumn{5}{|l|}{ Public Sector } \\
\hline Public Debt/GDP & 0.51 & 1.07 & 1.74 & 3.96 \\
\hline Public Expenditures & -0.23 & -0.57 & -0.91 & -1.48 \\
\hline Public Consumption & -0.23 & -0.57 & -0.91 & -1.48 \\
\hline Public Investment & -0.23 & -0.57 & -0.91 & -1.48 \\
\hline Investment in Human Capital & -0.23 & -0.57 & -0.91 & -1.48 \\
\hline Public Capital & -0.05 & -0.17 & -0.37 & -1.15 \\
\hline Human Capital & -0.01 & -0.02 & -0.06 & -0.29 \\
\hline Tax Revenues & 0.19 & 0.32 & 0.38 & -0.08 \\
\hline Personal Income Tax (IRS) & 0.15 & -0.29 & -0.82 & -1.27 \\
\hline Corporate Income Tax (IRC) & 0.20 & -0.33 & -1.01 & -1.83 \\
\hline Value Added Tax (IVA) & -0.73 & -0.83 & -0.88 & -0.99 \\
\hline Social Security Contributions (TSU) & -0.33 & -0.86 & -1.39 & -2.01 \\
\hline
\end{tabular}

These reductions are offset by the $\mathrm{CO}_{2}$ tax receipts. As a result, total tax revenue, in absolute terms, is $0.34 \%$ higher in 2030 . 


\section{On the Effects of an Indexed Carbon Tax with Revenue Recycling}

As an overall evaluation of the simple implementation of the indexed carbon tax - i.e., an implementation without recycling of its revenues - we can say that such a tax achieves significant reductions in emissions, a significant first dividend. Nevertheless, this comes at a cost of a significant slowdown in economic activity, and a small deterioration of the public-sector position. In that case, the second and third dividends do not materialize. In this section, we examine the effects when the carbon tax revenues are recycled in the quest for the key strategies leading to the realization of these second and third dividends.

\subsection{The Different Recycling Mechanisms}

The undesirable effects of the carbon tax in its simplest form can conceivably be eliminated, or even reversed, through careful recycling of tax revenues generated by the tax on $\mathrm{CO}_{2}$ emissions. In all cases, and in keeping with the institutional and political terms of the debate in Portugal, we assume that all recycling strategies satisfy strict tax-revenue neutrality on impact, that is, the revenues generated by the carbon tax are used to finance concomitant reductions in other tax margins. Since the assumption used to frame this issue is one of tax-revenue neutrality, that is, all carbon tax revenues are recycled in every year, and not one of general budgetary neutrality. Specifically, we do not consider other possible recycling strategies that would involve using the carbon tax revenues to finance increases in the different types of public expenditure.

We consider four revenue recycling mechanisms, i.e., four different tax margins will be alleviated by the use of carbon tax revenues - value-added tax (Imposto sobre o Valor Acrescentado, IVA), personal-income tax (Imposto sobre os Rendimentos de Pessoas Singulares, IRS), Social Security contributions paid by firms on their payrolls (Taxa Social Única, TSU) and an investment tax credit (Crédito Fiscal ao Investimento, CFI) in the context of the corporate-income tax. These four alternative recycling strategies cover the main economic mechanism to generate the mitigating effects operating 
through three separate channels - demand-driven (IVA), employment-driven (IRS on the labor supply side and TSU on the labor demand side), and investment-driven (CFI). In addition to these four mechanisms in isolation, we also consider mixed-recycling strategies which combine some of these individual mechanisms.

In addition to the four individual recycling cases and their judicious combination, we consider the effects of recycling when part of the recycled revenues are targeted specifically at promoting energy efficiency. An analysis of the Portuguese energy system using the TIMES_PT model [see Seixas and Fortes (2014)] suggests that energy-efficiency improvements equivalent to an average annual savings in primary energy consumption of 2.5-2.9\% between 2015 and 2030 are costeffective, in the absence any further climate policy. This means that there are technologies available which are in the best interest of all economic agents to adopt, based on cost considerations, independent of any environmental concerns or public incentives. Furthermore, with just 57 measures in energy efficiency enacted from 1990 to 2011, Portugal ranks 18 in the EU in terms of the numbers of measures adopted [see, for example, European Economy (2014)]. This evidence suggests that Portugal has significant room for improvement in terms of adopting further measures that promote energy efficiency. Moreover, EU-level mandated energy efficiency targets are becoming increasingly stringent and, therefore, steps in this direction are going to be critical over the next couple of decades.

A key issue when considering the targeting activities that promote energy efficiency is determining the levels of investment necessary to induce specific energy-efficiency gains. It is well understood that the mere presence of opportunities to improve energy efficiency that are costeffective is far from enough to lead to their subsequent adoption. As an illustration, public incentives in the form of subsidies are typically necessary. 
As a reference point, we use the value of 400 million euros in investment as the amount necessary to generate a 1,000 Ktoe of energy efficiency savings. This value is based on the average cost of avoided energy consumption at the industrial price in the US of $\$ 13.8$ per MMBTU, presented in the abatement cost structure in Granade et al. (2009). When applied to the Portuguese case, this unit value implies that a persistent annual increase in energy efficiency of about $1 \%$ of the total primary energy consumption would require a yearly investment of 85-100 million Euros. To put these figures in perspective, carbon tax revenues would start at around 160 million euros and, under our indexed tax, would increase to about 850 million Euros by 2030. This means that the resources required for these levels of investment necessary to induce annual gains in energy efficiency of up to $1 \%$ are readily available.

\subsection{On the Effects of the Different Individual Recycling Mechanisms}

The effects of the four individual recycling strategies are presented in the top panel of Table 3. We start with the case of using the revenues from the carbon tax to finance a reduction in the valueadded tax, IVA. This is a demand-driven case, as carbon tax revenues are used to boost private consumption by offsetting value-added tax revenues. The resulting $\mathrm{CO}_{2}$ tax revenue can finance an average $3.4 \%$ reduction in the value-added tax rate relative to the status quo over the next 15 years. The IVA-recycling strategy yields a small improvement in economic performance over the lumpsum recycling case, generating in the long term a weak realization of the second dividend - GDP falls by $0.71 \%$ while employment increases by a mere $0.08 \%$ in 2030 (employment falls by $-0.25 \%$ in 2050). This small improvement in GDP and in employment outcomes, relative to the lump-sum case, reflects the small distortions associated with indirect taxation. In turn, in terms of public debt, by 2030 we find a weak form of the third dividend (a strong form appears by 2050), that is, the public-debt-to-GDP ratio increases $1.18 \%$ (with public indebtedness falling $0.47 \%$ by 2050 ) vis-à-vis the reference scenario. 
Table 3

Effects of an Indexed Carbon Tax under Alternative Recycling Mechanisms

(Percent change with respect to reference scenario)

\begin{tabular}{|c|c|c|c|c|c|c|c|c|c|c|}
\hline & \multicolumn{2}{|c|}{$\begin{array}{c}\text { Carbon Dioxide } \\
\text { Emissions }\end{array}$} & \multicolumn{2}{|c|}{ Employment } & \multicolumn{2}{|c|}{ GDP } & \multicolumn{2}{|c|}{$\begin{array}{l}\text { Foreign Debt } \\
\text { /GDP }\end{array}$} & \multicolumn{2}{|c|}{$\begin{array}{l}\text { Public Debt } \\
\text { /GDP }\end{array}$} \\
\hline & 2030 & 2050 & 2030 & 2050 & 2030 & 2050 & 2030 & 2050 & 2030 & 2050 \\
\hline \multicolumn{11}{|c|}{ No Additional Energy Efficiency Gains } \\
\hline Lump Sum & -13.13 & -12.37 & -0.31 & -0.57 & -0.92 & -1.55 & -3.67 & -5.90 & 1.74 & 3.96 \\
\hline IVA/Value Added Tax & -12.97 & -12.36 & 0.08 & -0.25 & -0.71 & -1.53 & -5.47 & -8.47 & 1.18 & -0.47 \\
\hline IRS/Personal Income Tax & -12.62 & -11.56 & 0.54 & 0.46 & -0.25 & -0.44 & -0.53 & -1.38 & 0.55 & 2.10 \\
\hline TSU/Social Security Contribution & -12.77 & -11.82 & 0.29 & 0.12 & -0.45 & -0.79 & -1.90 & -3.70 & -0.51 & -3.01 \\
\hline CFI/Investment Tax Credit & -12.60 & -10.41 & -0.37 & 0.18 & -0.22 & 1.13 & 3.48 & 8.27 & 0.45 & 2.11 \\
\hline \multicolumn{11}{|c|}{ Additional Energy Efficiency Gain of $0.25 \%$} \\
\hline IVA/Value Added Tax & -14.07 & -13.38 & 0.07 & -0.24 & -0.64 & -1.40 & -4.99 & -7.78 & 0.91 & -1.07 \\
\hline IRS/Personal Income Tax & -13.73 & -12.60 & 0.52 & 0.46 & -0.18 & -0.32 & -0.14 & -0.83 & 0.30 & 1.47 \\
\hline TSU/Social Security Contribution & -13.87 & -12.85 & 0.27 & 0.13 & -0.38 & -0.67 & -1.49 & -3.11 & -0.75 & -3.56 \\
\hline CFI/Investment Tax Credit & -13.71 & -11.48 & -0.38 & 0.19 & -0.15 & 1.23 & 3.81 & 8.65 & 0.19 & 1.50 \\
\hline \multicolumn{11}{|c|}{ Additional Energy Efficiency Gain of 0.5\% } \\
\hline IVA/Value Added Tax & -15.13 & -14.35 & 0.06 & -0.23 & -0.57 & -1.27 & -4.53 & -7.12 & 0.65 & -1.65 \\
\hline IRS/Personal Income Tax & -14.80 & -13.60 & 0.50 & 0.46 & -0.12 & -0.21 & 0.23 & -0.31 & 0.05 & 0.87 \\
\hline TSU/Social Security Contribution & -14.94 & -13.84 & 0.26 & 0.14 & -0.31 & -0.55 & -1.10 & -2.55 & -0.99 & -4.09 \\
\hline CFI/Investment Tax Credit & -14.78 & -12.51 & -0.38 & 0.19 & -0.08 & 1.32 & 4.13 & 9.02 & -0.05 & 0.91 \\
\hline \multicolumn{11}{|c|}{ Additional Energy Efficiency Gain of 1.0\% } \\
\hline IVA/Value Added Tax & -17.13 & -16.19 & 0.04 & -0.21 & -0.43 & -1.03 & -3.68 & -5.90 & 0.16 & -2.73 \\
\hline IRS/Personal Income Tax & -16.82 & -15.48 & 0.47 & 0.46 & 0.00 & 0.00 & 0.92 & 0.67 & -0.41 & -0.26 \\
\hline TSU/Social Security Contribution & -16.95 & -15.71 & 0.23 & 0.15 & -0.18 & -0.33 & -0.37 & -1.50 & -1.43 & -5.09 \\
\hline CFI/Investment Tax Credit & -16.79 & -14.46 & -0.38 & 0.20 & 0.04 & 1.49 & 4.72 & 9.70 & -0.51 & -0.21 \\
\hline
\end{tabular}

Note: - Strong realizations of the second and third dividends are highlighted in boldface. 
The personal income tax, IRS, and the Social Security contributions, TSU, recycling cases are employment-driven mechanisms. These allow us to evaluate labor demand and supply responses to reductions in the tax burden on households and firms. On average, the $\mathrm{CO}_{2}$ tax revenues finance either a $4.8 \%$ reduction in the personal-income tax rate, or a 3.6\% reduction in Social Security contributions rate over the next 15 years, relative to the status quo.

Overall, these two employment-driven policies generate larger improvements in economic performance and larger reductions in the costs of climate policy than do the IVA-recycling strategy. Indeed, they both generate strong second dividends in terms of employment, and weak dividends in terms of GDP. They result in a $0.25 \%$ reduction in GDP for the IRS case and $0.45 \%$ for the TSU case, in both cases a weak realization of the second dividend. In turn, both the IRS and TSU recycling policies yield a strong realization of the second dividend, as it pertains to employment, as they generate gains of $0.54 \%$ and $0.29 \%$, respectively, by 2030 . Finally, the IRS case yields a weak realization of the third dividend with an increase of $0.55 \%$ in the debt-to-GDP ratio, while the TSU case leads to a strong realization with a $0.51 \%$ reduction in the debt-to-GDP ratio.

Finally, we examine the case of the investment-tax-credit recycling, CFI, in which $\mathrm{CO}_{2} \operatorname{tax}$ revenues are used to promote private investment. The resulting tax revenues could be used to finance, over the next 15 years, an investment tax credit worth on average $10.1 \%$ of all corporateincome (IRC) tax revenues.

As expected, the CFI policy stimulates private investment, but yields only weak forms of the second dividend by 2030, with a decrease in employment of $0.37 \%$ and in GDP of $0.22 \%$. By 2050 , however, employment increases by $0.18 \%$ and GDP by $1.13 \%$, in both cases a strong realization of the second dividend. Furthermore, we also observe a realization of the third dividend in its weak form, as public-debt-to GDP increases by 0.45 p.p. in 2030. 
The results for these policies, in which part of the revenues to be recycled are channeled to energy efficiency activities generating annual gains of $0.25 \%, 0.5 \%$ and $1.0 \%$, are reported in the three bottom panels of Table 3. In general terms, we observe that the use of these funds for energy efficiency purposes has a substantial effect on $\mathrm{CO}_{2}$ emissions. While reductions are in the 10.4$13.0 \%$ range in the absence of any further energy efficiency gains, they reach the $14.5-17.1 \%$ range when an additional efficiency gain of $1 \%$ is achieved. Naturally, this means that, from an environmental perspective, this use of the revenue is very significant, as it substantially deepens the emission reductions.

Equally important from our standpoint is the fact that allocating funds under the different recycling mechanisms to promote energy efficiency also yields substantial improvements in both economic and budgetary performance under each of the four different mechanisms. There is a strengthening of the weak realization of both the second and third dividends - the losses induced under the lump-sum case are greatly mitigated, and for a more robust performance of $1 \%$ in terms of energy efficiency, we actually observe a strong realization of the second and third dividend for the IRS and the CFI cases.

\subsection{On the Effects of Mixed Revenue Recycling Strategies}

The differences with respect to the economic and budgetary effects among the employmentdriven policies, the IRS and TSU policies, and the investment driven policy, CFI, suggest that combining these two types of policies may alleviate some of the short-term employment losses in the capital-investment-financing policies - as well as the negative long-term budgetary effects, while encouraging long-term growth through investment in physical capital. We leave out the IVA recycling case, as it fails to substantially mitigate the negative economic effects of the carbon tax in terms of either employment or output, compared to the lump sum case, the same being the case, albeit to a lesser degree, in terms of the budgetary effects. As such, the positive effects of the IVA 
recycling, relative to the lump sum case, are consistently dominated by the positive effects of the three remaining mechanisms.

For illustrative purposes, we consider three mixed strategies based on TSU, IRS and CFI recycling. In the first mixed strategy, the revenues of the carbon tax are evenly split between funding IRS reductions and CFI increases; in the second, they are evenly split between financing reductions in the TSU and more CFI; and, in the third, evenly split between the two employment driven mechanisms, IRS and TSU recycling policies, on one hand and the CFI on the other. The results are presented in Table 4.

In the case of simply recycling the carbon tax revenues without targeting additional energy efficiency improvements, we now observe the strong realization of the second dividend for both employment and GDP (in the longer term), the strongest case being the combination of CFI and IRS recycling. In turn, the strong realization of the third dividend also materializes with the mixed ITC- and TSU-recycling policy. Accordingly, even at this level, mixed strategies allow for the realization of the three dividends.

With recycling linked to increasing energy efficiency gains, the second dividend becomes generally stronger for both employment and GDP. From this perspective, again, the best outcomes come from a mixed strategy of CFI and IRS recycling. The third dividend, as well, becomes more pervasive as energy-efficiency gains increase, particularly when these exceed a $0.5 \%$ gain. From this perspective, the best outcome comes from mixed CFI and TSU recycling. Overall, the realization of the three dividends is a frequent outcome when considering simple mixes of recycling strategies with any degree of energy efficiency gains. 
Table 4

Effects of an Indexed Carbon tax under Mixed Recycling Mechanisms

\begin{tabular}{|c|c|c|c|c|c|c|c|c|c|c|c|c|}
\hline \multirow[b]{3}{*}{$\begin{array}{l}\text { CFI } \\
\text { Share }\end{array}$} & \multirow[b]{3}{*}{$\begin{array}{l}\text { TSU } \\
\text { Share }\end{array}$} & \multirow[b]{3}{*}{$\begin{array}{l}\text { IRS } \\
\text { Share }\end{array}$} & & & & & & & \multicolumn{4}{|c|}{ (Percent change with respect to reference scenario } \\
\hline & & & \multicolumn{2}{|c|}{$\begin{array}{l}\text { Carbon Dioxide } \\
\text { Emissions }\end{array}$} & \multicolumn{2}{|c|}{ Employment } & \multicolumn{2}{|c|}{ GDP } & \multicolumn{2}{|c|}{$\begin{array}{c}\text { Foreign Debt } \\
\text { /GDP }\end{array}$} & \multicolumn{2}{|c|}{$\begin{array}{l}\text { Public Debt } \\
\text { /GDP }\end{array}$} \\
\hline & & & 2030 & 2050 & 2030 & 2050 & 2030 & 2050 & 2030 & 2050 & 2030 & 2050 \\
\hline \multicolumn{13}{|c|}{ No Additional Energy Efficiency Gains } \\
\hline 0.50 & 0.00 & 0.50 & -12.61 & -10.97 & 0.08 & 0.32 & -0.23 & 0.37 & 1.56 & 3.62 & 0.48 & 2.07 \\
\hline 0.50 & 0.50 & 0.00 & -12.68 & -11.10 & -0.05 & 0.16 & -0.33 & 0.19 & 0.88 & 2.48 & -0.05 & -0.47 \\
\hline 0.50 & 0.25 & 0.25 & -12.64 & -11.04 & 0.02 & 0.24 & -0.28 & 0.28 & 1.22 & 3.05 & 0.22 & 0.80 \\
\hline \multicolumn{13}{|c|}{ Additional Energy Efficiency Gain of $0.25 \%$} \\
\hline 0.50 & 0.00 & 0.50 & -13.72 & -12.03 & 0.07 & 0.33 & -0.16 & 0.47 & 1.92 & 4.09 & 0.23 & 1.45 \\
\hline 0.50 & 0.50 & 0.00 & -13.79 & -12.15 & -0.06 & 0.16 & -0.26 & 0.29 & 1.25 & 2.96 & -0.30 & -1.05 \\
\hline 0.50 & 0.25 & 0.25 & -13.75 & -12.09 & 0.01 & 0.24 & -0.21 & 0.38 & 1.58 & 3.53 & -0.03 & 0.20 \\
\hline \multicolumn{13}{|c|}{ Additional Energy Efficiency Gain of 0.5\% } \\
\hline 0.50 & 0.00 & 0.50 & -14.79 & -13.04 & 0.06 & 0.33 & -0.10 & 0.57 & 2.26 & 4.52 & -0.02 & 0.85 \\
\hline 0.50 & 0.50 & 0.00 & -14.86 & -13.17 & -0.06 & 0.17 & -0.20 & 0.40 & 1.60 & 3.42 & -0.53 & -1.61 \\
\hline 0.50 & 0.25 & 0.25 & -14.82 & -13.10 & 0.00 & 0.25 & -0.15 & 0.49 & 1.93 & 3.97 & -0.28 & -0.38 \\
\hline \multicolumn{13}{|c|}{ Additional Energy Efficiency Gain of 1.0\% } \\
\hline 0.50 & 0.00 & 0.50 & -16.80 & -14.96 & 0.04 & 0.33 & 0.02 & 0.76 & 2.89 & 5.34 & -0.48 & -0.27 \\
\hline 0.50 & 0.50 & 0.00 & -16.87 & -15.08 & -0.08 & 0.18 & -0.07 & 0.59 & 2.25 & 4.28 & -0.98 & -2.67 \\
\hline 0.50 & 0.25 & 0.25 & -16.84 & -15.02 & -0.02 & 0.26 & -0.02 & 0.68 & 2.57 & 4.81 & -0.73 & -1.47 \\
\hline
\end{tabular}

Note: Strong realizations of the second and third dividends are highlighted in boldface.

\subsection{Effects of Partial Revenue Recycling}

Although recycling the $\mathrm{CO}_{2}$ tax revenue is important from both an economic and budgetary perspectives, it is also important to recognize that other considerations - such as environmental concerns, distributional considerations, and competitiveness concerns - may lead to a reduction in the amount of the net revenue that can be productively recycled. Furthermore, aside from the natural tendency for politicians to always prefer these additional revenues "with no strings attached" 
as it allows them extra fiscal space, there are institutional obstacles that hinder the direct earmarking of carbon tax revenues. The implementation of these strategies, albeit they have the potential to achieve a triple dividend in Portugal, will therefore, inevitably, be fraught with uncertainty.

Here we analyze the effects of a leakage in the amount of carbon tax revenues actually recycled under the mixed strategies under consideration, to determine the extent of such leakage in affecting the ability of such strategies to generate simultaneously desirable environmental, economic, and budgetary outcomes. We focus on the case with the most favorable of outcomes - i.e., the mixed cases with a $1 \%$ gain in energy efficiency, where all mixed strategies yield the three dividends. We consider cases in which only $25 \%, 50 \%$ and $75 \%$ of the revenues are actually recycled and the remainder is distributed lump sum to the households. Results are presented in Table 5.

Naturally, partial recycling of the $\mathrm{CO}_{2}$ tax revenues reduces the positive effects of each policy, relative to the lump sum case, as less of the recycled revenues are allocated to alleviating distortions at other tax margins. From the standpoint of achieving the second and third dividends, the results are very clear. Although the realization of the third dividend is not compromised by the partial recycling, the realization of the second one clearly is. In fact, in all cases where the strong dividend fails to occur, only $50 \%$ of the revenues, for example, are recycled. The realization of the second dividend disappears altogether when leakage of the recycling revenues reaches about 30-35\% (revenues recycled are $65-70 \%$ of total). There is an unequivocal conclusion that emerges: if the objective behind recycling is to achieve three dividends associated with the implementation of thecarbon tax, then most of the resulting extra revenues have to be recycled back into the economy aimed at alleviating those tax margins where distortions are most deleterious to economic growth. 


\section{Table 5}

\section{Effects of Partial Revenue Recycling}

(Mixed Recycling Strategies with Additional Energy Efficiency Gain of 1.0\%)

\begin{tabular}{|c|c|c|c|c|c|c|c|c|c|c|}
\hline & \multicolumn{2}{|c|}{$\begin{array}{c}\text { Carbon Dioxide } \\
\text { Emissions }\end{array}$} & \multicolumn{2}{|c|}{ Employment } & \multicolumn{2}{|c|}{ GDP } & \multicolumn{2}{|c|}{$\begin{array}{l}\text { Foreign Debt } \\
\text { /GDP }\end{array}$} & \multicolumn{2}{|c|}{$\begin{array}{l}\text { Public Debt } \\
\text { /GDP }\end{array}$} \\
\hline & 2030 & 2050 & 2030 & 2050 & 2030 & 2050 & 2030 & 2050 & 2030 & 2050 \\
\hline \multicolumn{11}{|c|}{$50 \%$ CFI and $50 \%$ IRS } \\
\hline $25 \%$ & -17.12 & -15.87 & -0.17 & -0.27 & -0.41 & -0.56 & -1.46 & -3.00 & -2.70 & -11.05 \\
\hline $50 \%$ & -17.01 & -15.56 & -0.10 & -0.07 & -0.27 & -0.12 & 0.01 & -0.16 & -1.96 & -7.45 \\
\hline $75 \%$ & -16.91 & -15.26 & -0.03 & 0.13 & -0.12 & 0.32 & 1.47 & 2.62 & -1.22 & -3.85 \\
\hline $100 \%$ & -16.80 & -14.96 & 0.04 & 0.33 & 0.02 & 0.76 & 2.89 & 5.34 & -0.48 & -0.27 \\
\hline \multicolumn{11}{|c|}{$50 \%$ CFI and $50 \%$ TSU } \\
\hline $25 \%$ & -17.13 & -15.90 & -0.20 & -0.31 & -0.44 & -0.60 & -1.62 & -3.27 & -2.83 & -11.65 \\
\hline $50 \%$ & -17.05 & -15.62 & -0.16 & -0.15 & -0.32 & -0.20 & -0.31 & -0.71 & -2.22 & -8.65 \\
\hline $75 \%$ & -16.96 & -15.35 & -0.12 & 0.01 & -0.19 & 0.20 & 0.98 & 1.81 & -1.60 & -5.66 \\
\hline $100 \%$ & -16.87 & -15.08 & -0.08 & 0.18 & -0.07 & 0.59 & 2.25 & 4.28 & -0.98 & -2.67 \\
\hline \multicolumn{11}{|c|}{$50 \%$ CFI, $25 \%$ TSU, and $25 \%$ IRS } \\
\hline $25 \%$ & -17.13 & -15.88 & -0.19 & -0.29 & -0.42 & -0.58 & -1.54 & -3.14 & -2.77 & -11.35 \\
\hline $50 \%$ & -17.03 & -15.59 & -0.13 & -0.11 & -0.29 & -0.16 & -0.15 & -0.43 & -2.09 & -8.05 \\
\hline $75 \%$ & -16.93 & -15.30 & -0.08 & 0.07 & -0.16 & 0.26 & 1.22 & 2.22 & -1.41 & -4.76 \\
\hline $100 \%$ & -16.84 & -15.02 & -0.02 & 0.26 & -0.02 & 0.68 & 2.57 & 4.81 & -0.73 & -1.47 \\
\hline
\end{tabular}

Note: Strong realizations of the second and third dividends are highlighted in boldface.

\section{On the Effects of Alternative Tax Levels}

Our focus on a carbon tax indexed to the central EU-ETS carbon market price projections has allowed for a detailed assessment of the mechanisms through which the tax jointly affects environmental outcomes, economic performance, and the public-sector account. It has also allowed us to assess the relative effects of different revenue-recycling policies. From a broader perspective associated with the choice among energy technologies or economic and political considerations - it 
is important to examine the impact of alternative levels of taxation. First, we consider a case in which we assume that the current prices observed in the EU-ETS carbon markets, i.e., a 5 Euros per $\mathrm{tCO}_{2}$, remain indefinitely in effect. Then, we consider an alternative in which prices in the carbon markets would immediately jump to levels projected for 2030, that is, a tax of 35 Euros per $\mathrm{tCO}_{2}$. These two cases provide a natural lower and upper bound on the effects of the indexed tax. The results are presented in Tables 6 and 7.

Naturally such dramatic alternatives in the level of carbon taxation have a significant impact on the realization of the first dividend. The emissions reductions are greatly reduced in the case of a steady 6 Euro tax, and amplified in the case of a steady 35 Euro tax, yet reflecting a pattern of decreasing marginal benefits of carbon taxation.

In terms of the effects on employment and GDP, we find that the gains from the mixedrecycling strategies increase with the carbon tax rate. The strong realization of the second dividend is more likely when there are greater carbon tax revenues available for reducing distortions at the other tax margins. In a sense, the opposite pattern occurs in terms of the strong realization of the third dividend. While for a lower tax level, virtually all cases, certainly all cases with energy efficiency gains, lead to a reduction in the debt-to-GDP ratio, for a higher tax rate reductions in the debt-toGDP ratio only occur under the mixed CFI and TSU case, as well as for the CFI and TSU/IRS case with higher energy efficiency gains. This is understandable, since public spending, by assumption, evolves proportionally to the now increasing GDP growth rate. Overall, while lower carbon tax rates make it easier for the second and third dividends to be simultaneously achieved, even high carbon tax rates allow for the realization of the triple dividend when recycling is coupled with in energy efficiency targets. 
Table 6

Effects of a Constant Carbon Tax of 5 Euros per tCO2

\begin{tabular}{|c|c|c|c|c|c|c|c|c|c|c|c|c|}
\hline \multirow[b]{2}{*}{$\begin{array}{l}\text { CFI } \\
\text { Share }\end{array}$} & \multirow[b]{2}{*}{$\begin{array}{l}\text { TSU } \\
\text { Share }\end{array}$} & \multirow[b]{2}{*}{$\begin{array}{l}\text { IRS } \\
\text { Share }\end{array}$} & \multicolumn{2}{|c|}{$\begin{array}{l}\text { Carbon Dioxide } \\
\text { Emissions }\end{array}$} & \multicolumn{2}{|c|}{ Employment } & \multicolumn{2}{|c|}{ GDP } & \multicolumn{2}{|c|}{$\begin{array}{l}\text { Foreign Debt } \\
\text { /GDP }\end{array}$} & \multicolumn{2}{|c|}{$\begin{array}{l}\text { Public Debt } \\
\text { /GDP }\end{array}$} \\
\hline & & & 2030 & 2050 & 2030 & 2050 & 2030 & 2050 & 2030 & 2050 & 2030 & 2050 \\
\hline \multicolumn{13}{|c|}{ No Additional Energy Efficiency Gains } \\
\hline 0.50 & 0.00 & 0.50 & -2.75 & -2.28 & 0.04 & 0.06 & 0.06 & 0.11 & 0.50 & 0.70 & 0.21 & 0.57 \\
\hline 0.50 & 0.50 & 0.00 & -2.77 & -2.31 & 0.02 & 0.03 & 0.04 & 0.08 & 0.42 & 0.52 & -0.04 & -0.09 \\
\hline 0.50 & 0.25 & 0.25 & -2.76 & -2.29 & 0.03 & 0.05 & 0.05 & 0.09 & 0.46 & 0.61 & 0.09 & 0.24 \\
\hline \multicolumn{13}{|c|}{ Additional Energy Efficiency Gain of $0.25 \%$} \\
\hline 0.50 & 0.00 & 0.50 & -4.01 & -3.46 & 0.03 & 0.07 & 0.12 & 0.22 & 0.88 & 1.21 & -0.03 & -0.03 \\
\hline 0.50 & 0.50 & 0.00 & -4.03 & -3.48 & 0.01 & 0.04 & 0.10 & 0.19 & 0.79 & 1.04 & -0.29 & -0.68 \\
\hline 0.50 & 0.25 & 0.25 & -4.02 & -3.47 & 0.02 & 0.05 & 0.11 & 0.20 & 0.83 & 1.13 & -0.16 & -0.35 \\
\hline \multicolumn{13}{|c|}{ Additional Energy Efficiency Gain of 0.5\% } \\
\hline 0.50 & 0.00 & 0.50 & -5.23 & -4.59 & 0.02 & 0.07 & 0.18 & 0.32 & 1.23 & 1.70 & -0.27 & -0.60 \\
\hline 0.50 & 0.50 & 0.00 & -5.24 & -4.61 & 0.00 & 0.05 & 0.16 & 0.29 & 1.15 & 1.53 & -0.53 & -1.24 \\
\hline 0.50 & 0.25 & 0.25 & -5.23 & -4.60 & 0.01 & 0.06 & 0.17 & 0.31 & 1.19 & 1.61 & -0.40 & -0.92 \\
\hline \multicolumn{13}{|c|}{ Additional Energy Efficiency Gain of 1.0\% } \\
\hline 0.50 & 0.00 & 0.50 & -7.52 & -6.73 & 0.01 & 0.09 & 0.30 & 0.52 & 1.89 & 2.61 & -0.73 & -1.68 \\
\hline 0.50 & 0.50 & 0.00 & -7.53 & -6.75 & -0.02 & 0.06 & 0.28 & 0.49 & 1.81 & 2.44 & -0.98 & -2.31 \\
\hline 0.50 & 0.25 & 0.25 & -7.52 & -6.74 & 0.00 & 0.07 & 0.29 & 0.50 & 1.85 & 2.52 & -0.85 & -2.00 \\
\hline
\end{tabular}

Note: Strong realizations of the second and third dividends. 
Table 7

Effects of a Constant Carbon Tax of 35 Euros per tCO2

\begin{tabular}{|c|c|c|c|c|c|c|c|c|c|c|c|c|}
\hline \multirow[b]{2}{*}{$\begin{array}{l}\text { CFI } \\
\text { Share }\end{array}$} & \multirow[b]{2}{*}{$\begin{array}{l}\text { TSU } \\
\text { Share }\end{array}$} & \multirow[b]{2}{*}{$\begin{array}{l}\text { IRS } \\
\text { Share }\end{array}$} & \multicolumn{2}{|c|}{$\begin{array}{l}\text { Carbon Dioxide } \\
\text { Emissions }\end{array}$} & \multicolumn{2}{|c|}{ Employment } & \multicolumn{2}{|c|}{ GDP } & \multicolumn{2}{|c|}{$\begin{array}{c}\text { Foreign Debt } \\
\text { /GDP }\end{array}$} & \multicolumn{2}{|c|}{$\begin{array}{l}\text { Public Debt } \\
\text { /GDP }\end{array}$} \\
\hline & & & 2030 & 2050 & 2030 & 2050 & 2030 & 2050 & 2030 & 2050 & 2030 & 2050 \\
\hline \multicolumn{13}{|c|}{ No Additional Energy Efficiency Gains } \\
\hline 0.50 & 0.00 & 0.50 & -12.02 & -10.28 & 0.23 & 0.32 & 0.27 & 0.52 & 2.60 & 3.66 & 1.30 & 3.38 \\
\hline 0.50 & 0.50 & 0.00 & -12.11 & -10.41 & 0.11 & 0.17 & 0.15 & 0.34 & 2.14 & 2.70 & -0.07 & -0.13 \\
\hline 0.50 & 0.25 & 0.25 & -12.07 & -10.34 & 0.17 & 0.25 & 0.21 & 0.43 & 2.37 & 3.18 & 0.61 & 1.62 \\
\hline \multicolumn{13}{|c|}{ Additional Energy Efficiency Gain of $0.25 \%$} \\
\hline 0.50 & 0.00 & 0.50 & -13.15 & -11.34 & 0.21 & 0.32 & 0.33 & 0.62 & 2.94 & 4.11 & 1.04 & 2.75 \\
\hline 0.50 & 0.50 & 0.00 & -13.23 & -11.47 & 0.10 & 0.18 & 0.21 & 0.45 & 2.49 & 3.18 & -0.31 & -0.72 \\
\hline 0.50 & 0.25 & 0.25 & -13.19 & -11.41 & 0.16 & 0.25 & 0.27 & 0.54 & 2.72 & 3.65 & 0.36 & 1.02 \\
\hline \multicolumn{13}{|c|}{ Additional Energy Efficiency Gain of 0.5\% } \\
\hline 0.50 & 0.00 & 0.50 & -14.23 & -12.37 & 0.20 & 0.33 & 0.39 & 0.72 & 3.27 & 4.55 & 0.79 & 2.14 \\
\hline 0.50 & 0.50 & 0.00 & -14.31 & -12.49 & 0.09 & 0.18 & 0.28 & 0.55 & 2.83 & 3.63 & -0.55 & -1.28 \\
\hline 0.50 & 0.25 & 0.25 & -14.27 & -12.43 & 0.15 & 0.26 & 0.33 & 0.64 & 3.05 & 4.09 & 0.12 & 0.43 \\
\hline \multicolumn{13}{|c|}{ Additional Energy Efficiency Gain of 1.0\% } \\
\hline 0.50 & 0.00 & 0.50 & -16.27 & -14.31 & 0.18 & 0.33 & 0.50 & 0.91 & 3.88 & 5.36 & 0.32 & 1.00 \\
\hline 0.50 & 0.50 & 0.00 & -16.35 & -14.42 & 0.07 & 0.19 & 0.39 & 0.74 & 3.45 & 4.48 & -1.00 & -2.34 \\
\hline 0.50 & 0.25 & 0.25 & -16.31 & -14.36 & 0.13 & 0.26 & 0.45 & 0.82 & 3.66 & 4.92 & -0.34 & -0.67 \\
\hline
\end{tabular}

Note: Strong realizations of the second and third dividends are highlighted in boldface.

\section{Summary and Final Remarks}

Our results highlight the environmental, economic and budgetary impact of the introduction a carbon tax indexed to the carbon market price in the EU-ETS. The introduction of a carbon tax in its simplest form, i.e., alone - absent accompanying revenue-recycling policies - reduces $\mathrm{CO}_{2}$ emissions significantly, but has a negative effect on economic performance, both in terms of output 
and in terms of employment. Furthermore, because of its contractionary effects, it would result in a small increase in the public-debt-to GDP ratio. In this form, a carbon tax would yield the desired first dividend, environmental improvements, but no second or third dividend, i.e, no economic or budgetary advantages, making it rather unacceptable from an economic policy perspective. Actually, quite the opposite would materialize. In the current domestic policy situation where boosting macroeconomic performance is a central objective and budgetary consolidation is an ongoing concern, these economic and budgetary effects would be undesirable serious obstacle to pursuing a green-tax reform, much to a loss for the environment.

Nonetheless, with the aid of numerical simulations, we have shown that it is possible to design a revenue-neutral tax reform package that yields the three dividends. Specifically, the introduction of a $\mathrm{CO}_{2}$ tax with accompanying reductions in distortionary tax rates can reduce emissions, while producing long-term economic and budgetary effects that are positive or, at a minimum, neutral. We find that the realization of the second and third dividends crucially depends on the judicious use of the revenues generated by the carbon tax.

The revenue-recycling policies that appear most promising in terms of simultaneously yielding the three dividends are those that use the revenue raised from the tax on $\mathrm{CO}_{2}$ emissions to finance private investment tax credits, a reduction in Social Security contributions paid by firms on their payrolls, and a reduction in the personal income tax rate in particular when these reductions are linked to energy-efficiency improving activities. Recycling the tax revenues through a mixture of these three mechanisms produces important changes in the cost structure of the Portuguese economy, by increasing the costs of energy while reducing the costs associated with the use of labor and capital inputs. These mixed strategies allow for the reduction in energy consumption and emissions, and, at the same time, allow for the decline in the costs of labor and capital that are key to spurring economic activity, boosting the various tax bases and subsequent tax revenues. Thus, they 
allow for the realization of all three dividends as both the economy and the budgetary situation are strengthened in the presence of a carbon tax.

Naturally, allowing for a leakage of a significant fraction of carbon tax revenues away from the purposes of financing reductions at other distortionary tax margins linked with energy efficiency gains would seriously hinder the ability of the alternative recycling strategies we considered to mitigate and invert the potential negative economic effects of the tax itself. Indeed, the recycling of carbon tax revenues as suggested here, aside from yielding the three dividends, has several other advantages as it creates a framework for neutralizing some of the legitimate concerns and special interests surrounding the issue of environmental tax reform. First, the focus on improving energy efficiency is fundamental from an economic and budgetary perspective. It is also important to accommodate the concerns of environmental groups, whose focus in terms of environmental tax reform seems to be exclusively on the first dividend - the environmental benefits of the reform and on the environmentally ethical view that carbon tax funds should be exclusively allocated to further improving the environment. In this sense, the proposal we contributed to, where a significant part of the carbon tax revenues ought to be allocated to activities designed to promote energy efficiency is likely to assuage these concerns.

Second, it is often understood that a carbon tax leads to distributional concerns, as lowerincome households may potentially suffer disproportionately from the tax when levied. For the three dividends to to achieved in Portugal, it is crucially important that these concerns not be addressed through carbon-tax exemptions, thereby neutralizing the price signal and environmental benefits associated with this surcharge. It is worth highlighting that these distributional concerns can be fully addressed within the context of a personal-income tax reform, while maintaining the price signal associated with the carbon tax. This recommendation is consistent with that of international institutions such as the OECD and the IMF, among others [see, for example, OECD (2011) and 
IMF (2014)]. Thus, the potential to recycle the $\mathrm{CO}_{2}$ tax revenue through a reduction in the personalincome tax rate discussed above, beyond its efficiency effects, can also serve this function by differentiating the reduction in the personal income tax rate in a manner that increases progressivity, thus supporting those lower income households that are somehow affected.

Third, there are also concerns that the carbon tax may possibly jeopardize international competitiveness by adversely affecting the cost structure of the firms producing traded goods. The crucial point, here, is that it is vital to abstain from addressing that these concerns through exemptions to the carbon tax, so as not to reduce the environmental effectiveness of the proposed green-tax reform. These concerns can be fully addressed either through a reduction in labor costs by reducing payroll taxes (TSU) or, alternatively, in the context of the provision of corporate income tax deductions for investments in private capital.

Finally, recycling carbon tax revenues by financing reductions in Social Security contributions - while desirable from an economic perspective in terms of its effect on output and employment (functioning in much the same way as a fiscal devaluation [see, for example, Pereira, Pereira and Rodrigues (2015)]) - must be accompanied by mechanisms to ensure that this reduction would never endanger the long-term sustainability of the public pensions and transfers system. Furthermore, caution is required to avoid the problems of political economy and the constitutional challenges inherent in changes in Social Security that are not linked to a comprehensive reform of the social security system.

As an epilogue to this article, it is worth mentioning that the evidence presented here was fully considered by the Portuguese Commission for Environmental Tax Reform (CRFV), and that the views and recommendations discussed here were fully incorporated in its official reform proposal. Specifically, the reform proposal envisaged a new carbon tax indexed to the EU-ETS, with the revenues to be used - in their entirety - to finance reductions in personal income taxes and in 
Social Security contributions, as well as increases in investment tax credits, always aimed at further promoting energy efficiency [see CRFV (2014)]. An indexed carbon tax, inspired by these proposals, was approved by the Portuguese Parliament in November of 2014, and has since then become law as of January $1^{\text {st }}, 2015$.

To conclude, it should be mentioned that, although this article focuses on the Portuguese case, and it served directly to inform policy making in Portugal, its interest is far from parochial. Naturally, climate and energy are at the forefront of the policy concerns and objectives in the EU [see, for example, European Commission (2014a, 2014b)] and, as such, all EU countries need to deal with these issues, albeit to different extents. In addition, there is a growing chorus of institutional voices urging all countries to adopt green taxes and to recycle their revenues to jumpstart their economies [see, for example Eurogroup (2014), IMF (2014), OECD (2014), Parry et al. (2014), and World Bank (2014)]. Furthermore, from a policy-evaluation perspective, the interactions between climate policy, economic growth and the public-sector account are fundamental, since they correlate to the most important policy constraints faced by energy-importing economies in their pursuit of sound climate policies: the need to pursue public policies that not only promote long-term economic growth, but also strengthen their public budgets.

\section{References}

Anderson, M., S. Speck, and D. Gee. 2013. "Environmental Fiscal Reform - Illustrative Potential for Portugal,” European Environment Agency Staff Position Note No. 13/01.

Babiker, M., G. Metcalf, and J. Reilly. 2003. Tax distortions and global climate policy. Journal of Environmental Economics and Management 46 (2): 269-287.

Comissão da Reforma da Fiscalidade Verde [CRFV]. 2014. Projecto de Refoma da Fiscalidade Verde, Ministério do Ambiente do Ordenamento do Território e da Energia. Lisboa, Portugal.

Dissou, Y. 2005. Cost-effectiveness of the performance standard system to reduce $\mathrm{CO}_{2}$ emissions in Canada: a general equilibrium analysis. Resource and Energy Economics 27(3): 187-207.

Esteves, P. 2014. Cenário da Evolução do Preço dos Combustíveis. Anexo II do Relatório Técnico "Sobre os Efeitos Ambientais e Económicos de uma Nova Tributação sobre o Carbono em 
Portugal- Anexo II”. Relatório Técnico apresentado à Comissão de Reforma da Fiscalidade Verde. Lisboa, Portugal.

Eurogroup. 2014. Structural Reform Agenda - Thematic Discussions on Growth and Jobs - Reduction of the Tax Wedge. Press Statement, July 8, 2014.

European Commission. 2013. Trends to 2050, Reference Scenario 2013. http://ec.europa.eu/energy/observatory/trends_2030/doc/trends_to_2050_update_2013.pdf

European Commission. 2014a. A Policy Framework for Climate and Energy in the Period 2020 up to 2030. Brussels.

European Commission. 2014b. Impact Assessment - Accompanying the Communication A Policy Framework for Climate and Energy in the Period 2020 up to 2030. Brussels.

Fullerton, D, and S, Kim. 2008. Environmental Investment and Policy with Distortionary Taxes and Endogenous Growth. Journal of Environmental Economics and Management 56(2): 141-154

Galston, W., and M. MacGuineas. 2010. The future is now: a balanced plan to stabilize public debt and promote economic growth. The Brooking Institution.

Goulder, L. 1995. Environmental taxation and the 'double dividend': a reader's guide. International Tax and Public Finance 2(2): 157-183.

Goulder, L., I. Parry, R. Williams, and D. Burtraw. 1999. The cost-effectiveness of alternative instruments for environmental protection in a second-best setting. Journal of Public Economics 72(3): 329-360.

Goulder, L., L. Bovenberg, and M. Jacobsen. 2008. Costs of alternative environmental policy instruments in the presence of industry compensation requirements. Journal of Public Economics 92 (5-6): 1236-1253.

International Monetary Fund. 2014. Fiscal Policy to Address Energy's Environmental Impacts. IMF Surveys.

Koetse, M., L. Henri, R. de Groot, and J. Florax. 2008. Capital-energy substitution and shifts in factor demand: A meta-analysis. Energy Economics 30(5): 2236-2251.

Granade, H, J, Creyts, A. Derkach, P. Farese, S. Nyquist, and K, Ostrowsly. 2009. Unlocking Energy Efficiency in the U.S. Economy. McKinsey Global Energy and Materials.

Manne, A., and R. Richels. 1992. Buying Greenhouse Insurance - the Economic Costs of Carbon Dioxide Emission Limits. MIT Press, Cambridge.

Marron, D., and E. Toder. 2014. Tax Policy Issues in Designing a Carbon Tax. American Economic Review Papers and Proceedings 104(5): 563-568.

Metcalf, G. 2010. On the use of carbon fees to achieve fiscal sustainability in the federal budget. Available at: http://works.bepress.com/gilbert_metcalf/86.

Metcalf, G., and D. Weisbach. 2008. The design of a carbon tax. Discussion Papers Series, 0727, Department of Economics, Tufts University.

Morris, J., S. Paltsev, and J. Reilly. 2012. Marginal Abatement Costs and Marginal Welfare Costs for Greenhouse Gas Emissions Reductions: Results from the EPPA Model 2012. Environmental Modeling and Assessment 17(4): 325-336.

Nordhaus, W. 1993a. Optimal Greenhouse-Gas Reductions and Tax Policy in the 'Dice' Model. American Economic Review 83(2): 313-17. 
Nordhaus, W. 1993b. Rolling the 'DICE': an optimal transition path for controlling greenhouse gases. Resource and Energy Economics, 15(1): 27-50.

Nordhaus, W. 2010. Carbon taxes to move toward fiscal sustainability. The Economists' Voice 7(3): Article 3.

OECD. 2011. Environmental Taxation: A Guide for Policy Makers. Brussels.

OECD. 2014. Deepening Structural Reform to Support Growth and Competitiveness. Brussels.

Oueslati, W. 2014. Environmental Tax Reform: Short-Term versus Long-Term Macroeconomic Effects. Journal of Macroeconomics 40: 190-201.

Oueslati, W. 2015. Growth and Welfare Effects of Environmental Tax Reform and Public Spending Policy. Economic Modelling 45: 1-13.

Paltsev, S., J. Reilly, H. Jacoby, R. Eckaus, J. McFarland, M. Sarofim, M. Asadoorian, and M. Babiker. 2005. "The MIT Emissions Prediction and Policy Analysis (EPPA) Model: Version 4," MIT Joint Program on the Science and Policy of Global Change Report 125.

Parry, I. 2014. Designing Fiscal Policy to Address the External Costs of Energy, CESifo working paper No 5128.

Parry, I., D. Heine, E. Lis, and L. Shanjun. 2014. Getting Energy Prices Right: From Principles to Practice. International Monetary Fund.

Pereira, A., and R. Pereira. 2012. DGEP - A dynamic general equilibrium model of the Portuguese economy: model documentation. The College of William and Mary, Working Paper 127 (Revised 2014).

Pereira, A., and R. Pereira. 2013. Fossil fuel prices and the economic and budgetary challenges of a small energy-importing economy: the case of Portugal. Portuguese Economic Journal 12(3): 181-214.

Pereira, A., and R. Pereira. 2014a. What is it going to take to achieve 2020 Emission Targets? Marginal abatement cost curves and the budgetary impact of CO2 taxation in Portugal. Working Papers 105, Department of Economics, College of William and Mary.

Pereira, A., and R. Pereira. 2014b. Environmental Fiscal Reform and Fiscal Consolidation: The Quest for the Third Dividend in Portugal. Public Finance Review 42(2): 222-253.

Pereira, A., and R. Pereira. 2014c. On the environmental, economic and budgetary impacts of fossil fuel prices: A dynamic general equilibrium analysis of the Portuguese case. Energy Economics 42(C): 248-261.

Pereira, A., and R. Pereira. 2014d. On the Relative Roles of Fossil Fuel Prices, Energy Efficiency, and Carbon Taxation in Reducing Carbon Dioxide Emissions: The Case of Portugal. Mimeo.

Pereira, A., R. Pereira, and P. Rodrigues. 2015. On the Long-Term Impact of a Fiscal Devaluation: An Application to the Portuguese Case. Ch. 6 in C. Amo-Yartley (Ed.) Fiscal Policies: International Aspects, Short and Long-Term Challenges and Macroeconomic Effects. Nova Publishers.

Pereira, A., and P. Rodrigues. 2002. On the Impact of a Tax Shock in Portugal. Portuguese Economic Journal 1(3): 205-236.

Pereira, A., and P. Rodrigues. 2004. Strategies for fiscal reform in the context of the EMU: the case of Portugal. Review of Development Economics 8(1): 143-165. 
Pereira, A., and P. Rodrigues. 2007. Social Security Reform in Portugal: A Dynamic General Equilibrium Analysis. Portuguese American Development Foundation, Lisbon.

Rivers, N., 2010. Impacts of climate policy on the competitiveness of Canadian industry: How big and how to mitigate? Energy Economics 32(5): 1092-1104.

Seixas, J., and P. Fortes. 2014. Avaliação do Impacto da Taxa de $\mathrm{CO}_{2}$ no Sistema Energético em Portugal o Modelo TIMES_PT. "Sobre os Efeitos Ambientais e Económicos de uma Nova Tributação sobre o Carbono em Portugal - Anexo III". Relatório Técnico apresentado à Comissão de Reforma da Fiscalidade Verde. Lisboa, Portugal.

Stern, N. 2007. The Economics of Climate Change: The Stern Review 2 Cambridge University Press.

World Bank. 2014. State and Trends of Carbon Pricing. World Bank, Washington, DC.

Xepapadeas, A. 2005. Economic growth and the environment. in K. Mäler, and J. Vincent (Ed.), Handbook of Environmental Economics 1(3): Ch. 23, 1219-1271. 